\begin{tabular}{r}
\hline \hline $811.163 .41: 378.4(100)(091)$ \\
$811.163 .41 ' 243(100)$ \\
https://doi.org/10.18485/msc_saopstenja.2018.48.1.ch2
\end{tabular}

Вељко Ж. БРБОРИЋ ${ }^{*}$

Универзитет у Београду

Филолошки факултет
Оригинални научни рад

Примљен: 02. 12. 2018.

Прихваћен: 03. 12. 2018.

\title{
БУДУЋНОСТ ЛЕКТОРАТА СРПСКОГ ЈЕЗИКА СА ОСВРТОМ НА ПРОШЛОСТ И САДАШњОСТ $* *$
}

У раду се говори о лекторатима српског језика на славистичким катедрама у свету. Наиме, у новим околностима, нестанком друге Југославије (почетком последње деценије двадесетога века) и слабљењем славистике на светским универзитетима, српски језик се нашао у веома неповољном положају. Направићемо краћи осврт на прошлост и садашњост наших лектората, али је основни задатак рада да покуша указати на значај лектората и да објасни како видимо њихову будућност. Будућност лектората српског језика на значајним славистичким катедрама посве је неизвесна и нужна је хитна интервенција државе (израда одговарајућих правилника и именовање комисије за лекторате) како бисмо дошли до прихватљивог решења.

Кључне речи: српски језик, лекторати, славистички центри, будућност лектората.

\section{Увод}

Свакој држави, свакој култури и сваком народу веома је значајно да матерњи (национални) језик има добар и стабилан статус у образовном систему. Истовремено, одговорне државе и њихове образовне и културне институције баве се промоцијом својих култура и националних језика и изван граница матичних држава. О заступљености српског језика у образовном систему последњих година се често говорило, тиме су се бавили наши истак-

\footnotetext{
*brboricv@eunet.rs

** Рад је резултат истраживања на пројекту Српски језик и његови ресурси: теорија, опис и примена (бр. 178006), који финансира Министарство просвете, науке и технолошког развоја Републике Србије.
} 
нути језички стручњаци (Ковачевић 2012; Драгићевић 2015; Пипер 2016). ${ }^{1}$ У Југославији, после Другог светског рата, стицајем различитих околности, у четири истојезичне републике у службеној је употреби био језик који се најчешће називао српскохрватски. Заправо, реч је о Вуковом и вуковском језичком идиому, који је у другој половини деветнаестог века био прихваћен и у Србији и изван граница Србије и изван Српства, пре стварања прве Југославије, оне која је створена 1918. године. ${ }^{2}$ Назив и избор језика функционисао је између два светска рата, а језичко ,јединство” после Другог светског рата додатно је ојачала нова власт, и то је и директно показано Новосадским књижевним договором из 1954. године. Један од закључака поменутог договора јасно каже: „У називу језика нужно је увек у службеној употреби истаћи оба његова саставна дела" (Правопис 1960: 7). Декларативно се, Новосадским договором, инсистирало и на два равноправна изговора и на два равноправна писма. Истина, у пракси су и постојала два изговора (ијекавски у Хрватској, Босни и Херцеговини и Црној Гори и екавски у Србији), али је, када је писмо у питању, латиница временом потискивала ћирилицу, у почетку постепено, а касније све јаче, па је данас ћирилица сведена само на употребу у Републици Србији и Републици Српској, док је на другим просторима раније заједничког српскохрватског језика практично више нема. Изван Србије нема ни екавског изговора, који је и раније био ограничен само на територију Републике $\mathrm{Cp}$ бије. Српски језик је данас службени у Републици Србији и Републици Српској, док је у осталим бившим републикама, данас самосталним државама, језик преименован у складу с националним називом већине становништва у осамостаљеним државама. Све се то одразило и на статус српског језика на славистичким катедрама. Већ смо констатовали да учење матерњег језика и у земљи, али и на славистичким катедрама у свету, представља важан део културе сваке земље. Није то само основно владање граматичком структуром и усвајање елементарне лексике, већ и бројна сазнања о културним, историјским, географским и другим особинама и вредностима земље о чијем језику је реч (Крајишник 2014). Преименовање српскохрватског језика директно се одразило на постојеће лекторате у иностранству. Оснивање лектората није једноставан посао, јер му претходе међудржавни, међууниверзитетски и међуфакултетски споразуми и уговори, али је оно посебно значајно у XXI веку, када су интеркултурализам и међународна сарадња израженији него што је то раније био случај.

\footnotetext{
${ }^{1} \mathrm{O}$ томе смо посебно говорили у раду Статус српског језика у образовном систему Србије (Брборић 2018).

${ }^{2}$ Истина, власти су језик 1918. године назвале српско-хрватско-словеначки, али су убрзо увиделе грешку и језик је између два светска рата најчешће називан српскохрватски, с повременим скраћивањем имена.
} 


\section{Прошлост и садашњост српског језика на славистичким катедрама}

У периоду после Другог светског рата владало је велико интересовање за славистику у свим светским лингвистичким центрима (на славистичким катедрама). У саставу славистичких катедара српскохрватски језик је имао добар статус и постоје неспорни подаци да је на бројним катедрама био на другом месту, одмах иза руског језика, који је с правом имао примат. Разуме се да су овде у питању били и нелингвистички разлози, па је српскохрватски језик негде имао статус студијске групе, негде двогодишњег, а негде једногодишњег (помоћног и изборног) предмета. Српскохрватски је тако изучаван на двоцифреном броју катедара у Француској, Италији, Немачкој и Пољској, али га је било и по целој Европи и на славистичким катедрама изван европског континента (Азија, Америка, Аустралија). Број лектората повећавао се из године у годину, па је осамдесетих година прошлог века достигао врхунац. Постоје егзактни подаци да је тада српскохрватски језик изучавало (студирало) око 10.000 студената, што се може сматрати великим успехом. Српскохрватски језик се у неком студијском облику изучавао у тридесетак земаља широм света: Аустрији, Аустралији, Албанији, Белгији, Белорусији, Бугарској, Великој Британији, Грчкој, Данској, Индији, Италији, Јапану, Канади, Јужној Кореји, Кини, Литванији, Мађарској, Немачкој, Норвешкој, Пољској, Португалији, Румунији, Русији, САД, Словачкој, Украјини, Француској, Чешкој, Швајцарској, Шведској, Шпанији итд. (Крајишник 2014)³

Када је, у последњој деценији двадесетога века, дошло да нестанка заједничке државе и када је на простору истојезичних република дошло до стварања четири државе и именовања четири различита језика (српског, хрватског, бошњачког и црногорског), то се директно одразило и на лекторате. Заправо, српскохрватски се на неким славистичким катедрама „угасио”, интересовање за словенске језике се смањило. Истовремено, на већини лектората назив језика је преименован, негде као хрватски, негде као хрватски и(ли) српски (српски и хрватски), а негде и као Б/Х/C (босански/хрватски/српски) језик. По нашим сазнањима, али и на основу проверљивих података, данас најбољи статус, када су посреди лекторати, има хрватски језик, српски је претрпео недопустиво смањење, док се бошњачки и црногорски полако боре за свој статус - негде у оквиру заједничке групације, а понегде и као самостални језици. Неспорно је да ће славистички центри поступати функционално и да неће успостављати четири засебне катедре за лингвистички исти (један) језик. Наравно, отварање и опстајање лектората везано је и за то какво је интересовање за неки језик, каква је реална потреба, каква је литература, култура и историја неке земље, али се тиче и неке врсте престижа у најширем смислу.

\footnotetext{
${ }^{3}$ Само је у Француској на 11 универзитета радило 18 лектора. Званично је било ангажовано 65 професора и/или лектора српскохрватског језика на иностраним факултетима.
} 


\section{Будућност српског језика на славистичким катедрама}

Наше је мишљење да је српски језик у новим околностима маргинализован и да је његов статус на славистичким катедрама неоправдано запостављен. Томе су допринели и наш немар и различите свеукупне околности (економске, политичке, културне и сл.). Када се сагледају све чињенице и уради нека врста пресека, онда се може рећи да лектори могу бити ангажовани на основу билатералне сарадње двеју држава, али и на основу међууниверзитетске (међуфакултетске) сарадње. Сарадња је могућа и на индивидуалној основи, ако постоји интересовање једне од две стране. У новим околностима пресудну је улогу имало затечено стање, али и активност и ангажовање и Републике Србије и одређеног славистичког центра. Србија је у последњој деценији двадесетог века, због санкција, била у образовној и културној изолацији. То се директно одразило и на наше лекторате у иностранству. По садашњем стању, слање лектора (давање сагласности) обавља Министарство просвете, али је нејасно ко лектора шаље, ко га плаћа и како се до избора лектора долази. ${ }^{4}$ Очигледно је да ово није добро уређено, није најсрећније регулисано и као да је препуштено стихији. Тако се може десити да у неком славистичком центру буде изабран (ангажован) лектор за српски језик, а да зато не знају наше просветне власти. Може се десити да лекторат нестане, а да то ми не знамо, или да српски језик предаје некомпетентна и нестручна особа. Све то може имати несагледиве образовне и културне последице и тада се поставља питање чија је то одговорност и како то поправити. Чињеница је и то да тренутно лектори раде у различитим условима и да услови, по правилу, зависе од земље пријема. Различита је и снабдевеност наставним средствима и она се односи и на техничку опремљеност и на одговарајућу литературу. Наша држава сигурно не може учествовати у техничкој опремљености лектора, али може у снабдевању лектората одговарајућом литературом, а то није нешто што се не може решити. Обично је теже организовање слања књига из Србије него њихова набавка. ${ }^{5}$

Будућност српског језика на славистичким катедрама данас је веома неизвесна. Због тога је нужна брза и добро осмишљена интервенција државе, али ни то није гаранција да ће српски језик добити сигуран статус на, за Србију важним, славистичким катедрама. О чему се заправо ради? Прво, мора постајати јасна воља и одлука наших институција да имамо лекторат у неком славистичком центру. Онда је потребно и да тај славистички центар и тамошње образовне власти покажу интересовање и разумевање, али и да постоји заинтересованост студената да уче српски језик. Јасно је да лекторат не може опстати ако нема интересовања студената, јасно је да ми нисмо велики језик

\footnotetext{
${ }^{4}$ Дуго је овај посао обављао републички Завод за међународну научну, техничку, просветну и културну сарадњу, али је он као институција нестао. Његове послове преузело је Министарство просвете и тако су, уз постојеће, настали и нови проблеми (Банаух/Бјелановић 2014).

${ }^{5}$ Народна библиотека Србија често шаље књиге и има добру сарадњу са свим лекторатима који показују интересовање за књиге из Србије (Славистички центри 2017). Слање књига често зависи од ангажовања лектора.
} 
и јасно је да имамо конкуренцију у бившим истојезичним републикама и новонасталим језицима. Ово је посебно изражено у новим условима, када су тамошње катедре и њихове просветне власти свесне да српскохрватски језик јесте лингвистички један језик и да није могуће имати убудуће одвојено студенте за новоименоване језике.

Ипак, мислимо да будућност лектората српског језика на славистичким катедрама зависи од неколико елемената, а ми смо их груписали у четири тачке: 1. Прво морамо имати прецизан попис где се сада изучава српски језик и у ком формату (ко је лектор српског језика, по ком основу је ангажован и колико има студената); 2. Република Србија, тј. просветне власти (Министарство просвете), у сарадњи са Министарством културе и Министарством спољних послова, морају јасно одредити шта су наши приоритети и где морамо одмах успоставити лекторате српског језика и шта је наш коначни циљ. Разуме се да овде вреди проверити и билатералне споразуме са државама где се изучава славистика и где је раније било српскохрватског језика. Дакле, морају се одредити приоритети и мора се направити дугорочна стратегија када је ова област у питању. Може то бити и вишегодишњи (деценијски план). Циљ мора бити јасан и прецизан, као и рокови за његово извршење. 3 . Потребно је израдити одговарајуће правилнике и именовати одговарајуће комисије, што нам сада недостаје. ${ }^{6}$ Правилници и упутства морају бити усклађени са реалном ситуацијом и са нашим реалним потребама. Комисије морају бити састављене од представника филолошких (филозофских) факултета у Србији, оних на којима се изучавају националне дисциплине, али и од представника ресорних министарстава. Подразумева се да руководилац посла треба да буде Министарство просвете. Свакако вреди консултовати и релевантне институције, као што су Међународни славистички центар и Центар за српски као страни језик, обе са Филолошког факултета у Београду. ${ }^{7}$ 4. Мора се решити и проблем финансирања, јер је то озбиљан посао. Наиме, неке лекторе, као што је то сада случај, плаћаће факултети на којима они држе наставу, у неким случајевима ће Србија учествовати у делу плаћања, док ће понегде све трошкове сносити Србија. Са неким центрима се може направити реципроцитет и то је најједноставнији облик сарадње. У неким центрима тамошња плата није довољна и Србија мора учествовати у финансирању лектора. Постоје и случајеви где ће све трошкове лектора морати да преузме Србија, а то су они центри где ми имамо посебан интерес за постојање лектората српског језика или где та држава (славистички центар) већ плаћа свога лектора у Србији. Сви ангажовани лектори би Министарству просвете подносили годишње извештаје. Лектори би се најмање једном годишње окупљали у Београду или у Тршићу и решавали проблеме са којима се сусрећу. Тако би Министарство

\footnotetext{
${ }^{6}$ Изменама Закона о високом образовању, који је донет у јесен 2018, додат је члан 83 а и тиме су створени законски услови да се проблеми лектората реше.

${ }^{7}$ Наше је мишљење да значајну улогу у овоме може и мора имати Филолошки факултет у Београду, заједно са Међународним славистичким центром и Центром за српски као страни језик. Ово никако не значи да су други филолошки центри искључени. Овде мислимо на све универзитетске центре где се изучавају српски језик и књижевност (Нови Сад, Ниш, Крагујевац, Косовска Митровица и Нови Пазар).
} 
просвете имало потпуни увид у изучавање српског језика у страним славистичким центрима.

Дакле, будућност лектората ће зависити од одлука наших просветних власти, али и од стања славистике у европским и светским лингвистичким центрима. Ипак, овде желимо поновити да је у питању озбиљан друштвени задатак и да он има велики значај за просветну и културну политику наше земље.

Министарство просвете мора именовати Комисију за лекторате, која ће сачинити програм рада, прикупити све потребне податке и понудити одговарајућа решења.

Разуме се да је потребно проверити са којим државама имамо потписане билатералне (међудржавне, међууниверзитетске или међуфакултетске) уговоре и прецизирати културну и образовну сарадњу. Свакако да би приоритет имале земље у окружењу, али и важни славистички центри у Европи и изван ње.

Пошто је о овим проблемима било доста речи последњих година, коначно је у 2018. години учињено неколико конкретних потеза. Наиме, констатовано је да је услед немара ситуација лоша и да је нужно да се стање поправи. Тако је 2017. и 2018. године одржано неколико састанака и разговора три надлежна министарства (Министарства просвете, Министарства културе и Министарства спољних послова). Посебан проблем представљала је чињеница да се у Закону о високом образовању нигде не помињу лекторати и да недостају одговарајући правилници. Чини се да је иницијатива кренула од Министарства културе и информисања, па је Министарство просвете реаговало и решило да уреди ову област. О чему се заправо ради?

Прво је министар просвете именовао комисију која је добила задатак да изради одговарајуће Упутство. Комисија се састојала од представника министарстава, али и од представника Филолошког факултета у Београду, ${ }^{8}$ Филозофског факултета у Новом Саду и Филозофског факултета у Нишу. Комисија је урадила предлог Упутства и доставила га министру просвете. Његов пуни назив гласи: Упутство о условима за избор и заснивање радног односа лектора српског језика и кьижевности на страним високошколским установама.

\section{Нека решења Упутства и њихова објашњења}

Овде ћемо дати неке изводе из Упутства и настојати да их објаснимо. Први задатак Упутства био је да се прецизира ко може бити именован (изабран) за лектора српског језика у иностранству.То је прецизирано у члану 2 Упутства, који гласи:

„За лектора српског језика и књижевности на страним високошколским установама може бити изабрана особа: која има завршене основне студије српског језика и књижевности или студије филологије и мастер студије српског језика и књижевности, или српског

${ }^{8}$ У Комисији сам поред проф. др Љиљане Бајић, продекана Филолошког факултета у Београду, и ја био члан Комисије, као представник Филолошког факултета. 
језика као страног, или мастер филологије на једном од универзитета у Републици Србији; зна један светски језик/језик земље пријема на нивоу Б1 Заједничког европског оквира; има најмање две године радног искуства у струци.

Ако је кандидат завршио студије страног језика, неопходно је да у току студија има положен српски језик у трајању од најмање два семестра.

Предност при избору има кандидат са завршеним студијама у области српског језика и књижевности, кандидат са већом просечном оценом на основним и мастер студијама, кандидат са објављеним радовима и наградама, кандидат са радним искуством. Уколико на конкурсу нема кандидата са радним искуством, може бити изабран и кандидат без радног искуства, уз препоруку два професора одговарајућег факултета" (Упутство 2018: 1).

Као што се види, члан 2 Упутства постављен је прилично широко и мислимо да је то добро. Не би било добро да се за лектора српског језика шаље само дипломирани србиста (српски језик и књижевност), јер из искуства знамо да је било и другачијих случајева и да је то пракса и код других држава. Истина, Упутство каже да предност „при избору има кандидат са завршеним студијама у области српског језика и књижевности”, односно кандидат са већом просечном оценом, са објављеним радовима и са радним искуством. Овај члан говори и да будући лектор мора да поседује знање светског језика или језика земље пријема на нивоу Б1 Заједничког европског оквира. Дакле, дипломирани србиста мора знати један светски језик или језик земље пријема. Комисја се определила за ниво Б1 због тога што није лако утврдити како се страни језици предају на нашим филолошким (филозофским) факултетима и нисмо хтели да Упутство буде ограничавајуће. За лектора може бити изабран и дипломирани филолог страног језика и књижевности, али је услов да је на студијама имао српски језик као наставни предмет у трајању од најмање једне школске године (два семестра). И овде смо настојали бити опрезни, јер је учење српског језика на страним филологијама неуједначено и постојала је опасност да Упутство буде престрого и да неки наши универзитетски центри унапред буду искључени. ${ }^{9}$

Врло је важно да се избор лектора обавља јавно и Упутство је то прописало чланом бр. 3, који гласи:

„Лектори се бирају на основу јавног конкурса који расписује Министарство надлежно за просвету (у даљем тексту: Министарство). Конкурс се објављује у дневном листу и на званичној интернет страници Министарства” (Упутство 2018: 1).

Овакав поступак је врло јасан, оправдан и није га нужно посебно коментарисати. Јавни конкурс обезбеђује право свих који испуњавају услове да се могу јавити на конкурс и да се може имати увид у цео поступак избора.

Свакако је најважнији део избор одговарајућег лектора и Упутство предвиђа да се именује Комисија за лекторате, која би, тако је бар замишљено, изабрала најбољег кандидата који се пријави на расписани конкурс. Поступак избора и именовања лектора прописан је чланом бр. 4 и он гласи:

${ }^{9}$ Разуме се да ће бити коментара на овакав поступак Комисије о знању страног језика за дипломираног србисту или знању српског језика за дипломираног филолога страног језика, али смо сматрали да се не сме бити искључив, јер ће избор лектора вршити стручна комисија и намера је била да Упутство буде нешто шире. 
„Поступак избора лектора спроводи Комисија за лекторате српског језика (у даљем тексту: Комисија за лекторате), коју именује Министарство на период од пет година и у којој су најмање два представника министарства и по један представник три матична факултета.

Комисија за лекторате предлаже Министарству ужи избор кандидата, уз образложење предлога.

Министарство, на основу предлога Комисије за лекторате, предлаже страној високошколској установи кандидата за лектора из најужег избора кандидата који испуњавају услове конкурса.

Документација предложеног кандидата упућује се дипломатским путем страној високошколској установи.

Лектор се сматра изабраним кад Министарство прими од високошколске установе сагласност за његов избор" (Упутство 2018: 2).

Упутство је прилично прецизно дефинисало и обавезе које имају лектори:

„Лектори су обавезни да обављају следеће послове: да држе предавања и изводе практичне вежбе из српског језика, српске књижевности и културе; ако је потребно, уколико то катедра затражи од њих, могу држати предавања из историје језика, дијалектологије, историје културе Срба и других сродних дисциплина; преносе културну и уметничку баштину Републике Србије; када то страна високошколска установа захтева од лектора, обављају и друге послове везане за радно место на које су распоређени" (Упутство 2018: $2-3)$.

Потпуни увид у рад лектората могуће је имати уколико лектори подносе одговарајуће извештаје и уколико о томе постоји писани траг, што сада није случај. Овде видимо и простор за усавршавање лектора, размену искустава и њихово редовно окупљање. Упутство је и то настојало да регулише. О томе говори члан 10 Упутства:

„Лектори су обавезни да доставе Министарству писану потврду - исправу стране високошколске установе о обављеном послу на крају сваког семестра.

Обавезни су, такође, да два пута годишње (на крају сваког семестра) доставе извештај о свом раду Министарству и Комисији за лекторате.

Комисија за лекторате предлаже програм стручног усавршавања за унапређивање академских и наставничких компетенција лектора, а факултети реализују предложене програме у оквиру својих академских и стручних активности.

Комисија за лекторате, у току године, организује периодично састанак свих лектора српског језика да би се континуирано разматрали проблеми и предлози за унапређивање квалитета извођења наставе српског језика у иностранству" (Упутство 2018: 3, члан 10).

Упутство је, на неки начин, прецизирало и како се решава проблем обавезне литературе, али и опремање лектората одговарајућим наставним средствима. Овде се очекује помоћ Народне библиотеке Србије, али и помоћ ресорних министарстава.

Посебна пажња у Упутству односи се и на финансирање лектора, о чему говори члан 13:

„Средства за исплату плата и осталих новчаних накнада за рад лектора на страним високошколским установама осигурава Министарство из буџета Републике Србије за текућу годину, у складу са одлуком Министарства. 
Предлог о врсти и износу финансијске подршке лекторима, уз образложење и одговарајућу документацију, достављају матични факултети Министарству. Приликом одлучивања о наведеним питањима, Министарство ће консултовати и надлежно дипломатскоконзуларно представништво Републике Србије.

Доприносе за пензијско и здравствено осигурање за лекторе на страним високошколским установама уплаћује Министарство у складу са прописима Републике Србије” (Упутство 2018: 4, члан 13).

Комисија је завршила посао у јулу 2018. године и Упутство о условима за избор и заснивања радног односа лектора српског језика и књижевности на страним високошколским установама проследила министру просвете. Проблем је био изостанак лектората у постојећем Закону о образовању. С обзиром на то, крајем септембра 2018. године урађене су измене и допуне Закона о високом образовању, у Закон је додат члан 83 а и он носи поднаслов Лектори српског језика на високошколским установама у иностранству. Увидом у предлог овог члана (члан 83a) можемо констатовати да је суштина урађеног Упутства уграђена у овај члан и да је тиме створен законски основ да се овај вишегодишњи проблем реши. ${ }^{10}$ Дакле, тако је после дужег чекања учињен озбиљан помак.

Овде се нисмо бавили сарадњом са бившим истојезичним републикама, сада самосталним државама. Ипак, мислимо да је лако направити сарадњу са Републиком Српском, верујемо да је то и оправдано, док ће свакако на ред доћи и разговори и око лектората са Хрватском, Црном Гором и Босном и Херцеговином.

\section{Закључак}

Стање лектората српског језика у славистичким центрима је веома неповољно, па је и њихова будућност прилично неизвесна. Потребна је хитна интервенција државе, односно просветних власти и ресорних министарстава.

Радује сазнање да су у изменама и допунама Закона о високом образовању, који је у јесен 2018. прошао скупштинску процедуру, лекторати нашли своје место, чиме су створени услови да се ова област ваљано уреди.

Потребно је сада израдити одговарајуће правилнике и упутства и тиме коначно решити ову важну област.

Разуме се да је ово посао где се очекује велико ангажовање Министарства просвете, сарадња са Министарством културе и Министарством спољних послова, али и сарадња са одговарајућим факултетима и центрима може гарантовати успех. Ипак, ово је само почетак, морамо прецизно утврдити постојеће стање, одредити наше приоритете и наћи најбоље начине да их решимо. У сваком случају, чека нас озбиљан посао.

\footnotetext{
${ }^{10}$ Консултовали смо радну верзију Закона, која је носила датум 5. 10. 2018. године. После тога је Закон прошао регуларну скупштинску процедуру, али се текстом Закона нисмо бавили у овом раду.
} 


\section{ЛИТЕРАТУРА}

Банаух/Бјелановић 2014: Бланка Банаух-Бјелановић, Положај српског језика као страног у земљи и у иностранству, у: Српски као страни језик у теорији и пракси, Београд: Филолошки факултет, 243-245.

Брборић 2018: Вељко Брборић, Статус српског језика у образовном систему Србије, у: Језици образовања, Београд: Филолошки факултет, 81-94.

Драгићевић 2015: Рајна Драгићевић, Нека питања организације наставе српског језика као важан фактор очувања идентитета српског језика и културе, Узданииа, год. XII, бр. 1, Јагодина, 117-129.

Изучавање сј 2010: Изучавање српског језика и књижевности на страним универзитетима - актуелно стање (материјал Министарства спољних послова, Одељења за међународну културну, просветну, научну, технолошку и спортску сарадњу), Београд, 1-87.

Ковачевић 2012: Милош Ковачевић, Статус српског језика на српским универзитетима, у: Филологија и универзитет (тематски зборник радова), Ниш: Филозофски факултет, 13-16.

Крајишник 2014: Весна Крајишник, Лекторати српског језика, у: Српски језик и актуелна питања језичке политике, Зборник Института за српски језик САНУ II, Београд: Институт за српски језик САНУ, 217-226.

Пипер 2016: Предраг Пипер, Српски језик између великих и малих језика, Кюижевност и језик, LXIII/1-2, 1-17.

Правопис 1960: Правопис српскохрватскога књижевног језика, Нови Сад - Загреб: Матица српска-Матица хрватска.

Славистички центри 2017: Славистички центри - материјал Народне библиотеке Србије, Београд, 1-31.

Упутство 2018: Упутство о условима за избор и заснивање радног односа лектора српског језика и књижевности на страним високошколским установама (радни материјал), 1-5.

Veljko Ž. Brborić

THE FUTURE OF THE SERBIAN LANGUAGE LECTORATES WITH THE REVIEW OF THE PAST AND PRESENT

Summary

This work discusses the Serbian language lectorates at the Slavic departments in the world. Namely, in the new circumstances - the disappearance of the second Yugoslavia (at the beginning of the last decade of the twentieth century), as well as the weakening of interest in Slavic studies at international universities - the Serbian language was in a rather poor position. We will make a brief review of the past and present of our lectorates, but the main task of the work is to try to point out the importance of the lectorates and to explain how we see their future. The future of the Serbian language lectorates depends on the urgent reaction of the educational authorities and the relevant institutions. 